\title{
Role of Democracy Assessment Tools in Democracy Consolidation: Lessons Learned From Mongolia
}

\author{
G. C huluunbaatar (M ongolia) and T odd L andman (U K)
}

\section{Contents}

1. Executive summary

2. Background

3. Aims and Objectives of the Follow-Up to ICNRD-5

4. Activities and outputs

5. Methods

6. Main outputs

- Desk Studies

- Democratic governnance Indicators

- Country Information Note

- Urban Governance Index(UGI) and Civil Society Index(CSI)

7. Outcomes and Lessons

8. Conclusions

\section{Executive summary}

1. Democracy assessment in Mongolia was a state-led exercise conducted as part of the follow-up activities to the $5^{\text {th }}$ International Conference of New or Restored Democracies and involved the active participation of the Government, Parliament, and Civil Society.

2. The process of democracy assessment itself provided a unique opportunity for critical self-reflection within Mongolia about the quality of democracy, the performance of democratic institutions, and elite and mass perceptions of democracy.

3. The follow-up activities successfully generated methods for assessing democracy in the particular context of Mongolia using comparable concepts and measures employed in the measurement and assessment of democracy in other developed and developing democracies around the world, as well as a series of 'satellite' indicators that captured aspects of democracy particular to the Mongolian national context.

4. Mongolia has built on the assessment process by institutionalising a democratic reform agenda through the passage of the $9^{\text {th }}$ Millennium Development Goal on democracy, human rights, and zero tolerance of corruption. 


\section{Background}

The International Conference on New or Restored Democracies (ICNRD) is an intergovernmental process open to all UN member States. Since the first Conference was held with the participation of 13 countries, the ICNRD has grown into a global event bringing together more than 100 countries from the developing and developed world. To date, a total of five International Conferences on New or Restored Democracies have been held in Manila, the Philippines (1988); Managua, Nicaragua (1994); Bucharest, Romania (1997); Cotonou, Benin (2000) and the latest in Ulaanbaatar, Mongolia (2003). The ICNRD movement recognizes that new or restored democracies face multiple challenges brought about by both national and international forces. Although democracy has advanced rapidly in great parts of the world over the last thirty years, many countries are struggling to consolidate their sovereignty, their democratic achievements, and making democracy itself an irreversible process. New or restored democracies have pledged to ensure that all members of society benefit from the democratization process and are able to participate fully in their new systems of governance. ICNRD represents a forum to discuss and exchange views on democratic governance and developmental issues.

In September 2003, Mongolia hosted the Fifth International Conference of New or Restored Democracies (ICNRD-5), which brought together over 500 participants from 119 States to discuss democracy, good governance and civil society. The record number of countries and high level of participants at the Fifth ICNRD held in Ulaanbaatar demonstrated increasing global support to discuss and promote democratization at the national, regional and global levels. The Ulaanbaatar Declaration that resulted from the conference and endorsed by the Fifth ICNRD sets forth six key principles that democratic societies are:

1. just and responsible

2. inclusive and participatory

3. promote and protect the rights and freedoms of all their members

4. open and transparent

5. function under agreed rules of law and accountability regardless of the challenges they may face

6. show solidarity toward others

In addition to the Ulaanbaatar Declaration, the conference adopted the most far reaching ICNRD Plan of Action to date that commits participating governments to implement ambitious plans on strengthening democracy along with concrete tools such as democratic governance indicator databases to monitor democratic progress over time.

One of the innovations of the Fifth ICNRD was to hold a threefold activity comprising the inter-governmental conference, Civil Society Forum, and the Parliamentarians Forum. The findings and recommendations of the Civil Society and Parliamentarian forums were presented to the ICNRD and fed into the final Conference documents. The Parliamentarian and Civil Society members also 


\section{G. C huluunbaatar and Todd L andman}

pledged to institute their own follow-up mechanism to monitor progress. There was broad consensus at the 2003 Conference for ICNRD to institutionalize the tripartite structure of government, civil society and parliament.

As part of its leadership of ICNRD-5, Mongolia used the International IDEA framework for democracy assessment to carry out a series of activities aimed at assessing and reforming democracy. This paper shares the main lessons learned from the role of democracy assessment in the further consolidation of democracy. First, it argues that the process of democracy assessment itself, which was grounded in wide consultation and participation of all major stakeholders, provided a unique opportunity for critical self-reflection within Mongolia about the quality of democracy, the performance of democratic institutions, and elite and mass perceptions of democracy. Second, it shows that the follow-up activities successfully generated methods for assessing democracy in the particular context of Mongolia using comparable concepts and measures employed in the measurement and assessment of democracy in other developed and developing democracies around the world. Third, it demonstrates that Mongolia has built on the assessment process by institutionalising a democratic reform agenda through the passage of the $9^{\text {th }}$ Millennium Development Goal on democracy, human rights, and zero tolerance of corruption.

\section{Aims and Objectives of the Follow-Up to ICNRD-5}

As host and chair of ICNRD-5 and with the support of UNDP Mongolia developed an ICNRD-5 Follow-Up Project to implement a number of pioneering activities in line with the 2003 Conference recommendations. Since improving the quality of democracy has become a political demand in both new or restored and mature democracies, there is a growing need to assess the progress in democratization and the quality of democracy itself. The ICNRD-5 outcome documents contain an explicit commitment by the governments of new or restored democracies along with their counterparts from mature democracies to develop assessment tools to be better able to monitor progress in democratic and social development over time.

The follow-up project to ICNRD-5 identified the following main aims and objectives:

1. Assess the depth and breadth of democracy

2. Broaden participation in the democratic process through building capacity

3. Engage the government, parliament, and civil society in a national process

4. Develop a set of concrete policies to enhance and consolidate democracy

5. Institutionalize a system for producing annual democratic governance indicators

6. Disseminate findings and share lessons with regional and international partners in ICNRD 


\section{Activities and Outputs}

The Government of Mongolia and the UNDP identified a series of inter-related activities and outputs that would lead to the realization of the main aims and objectives of the follow-up project, including the development of Democratic Governance Indicators (DGIs), a Country Information Note (CIN), and a National Plan Of Action (NPA), as well a series of national and international events and other complementary activities (see Figure 1). It is envisioned that the DGIs, CIN and NPA will help Mongolian stakeholders create a baseline assessment, an ongoing monitoring-mechanism and offer policy guidance to realize its Millennium Development Goals.

In January 2005, a delegation from the Ministry of Foreign Affairs and UNDP engaged in a series of international consultations with The International Institute for Democracy and Electoral Assistance (International IDEA) in Stockholm and the UNDP's Oslo Governance Centre to learn more about best practices in the areas of democracy assessment and the development of governance indicators. The delegation selected International IDEA's 'State of Democracy' framework and methodology for democracy assessment as the basis for the development of democratic governance indicators in Mongolia.

The project sponsored two national events on democracy in Mongolia that included all national stakeholders, country delegations, international guests, and experts. These events have enabled a national all-inclusive forum to discuss the quality of democracy in the country, its opportunities and challenges, and the democratic solutions to crucial developmental issues that Mongolia faces.

The June 2005 conference 'Democracy Development in Mongolia' presented preliminary findings from the work on the development of democratic governance indicators, consulted stakeholders on a variety of issues and challenges confronting Mongolian democracy, and was followed by a two-day technical workshop with the academic research team, members of civil society, and international experts on democracy assessment.

The June 2006 Follow-Up Conference presented the main final outputs of the project, including the Democratic Governance Indicators (DGIs), the Country Information Note (CIN), and the national plan of action (NPA), as well as two desk studies (see below). Participants included country delegations, representatives from international donor organizations, inter-governmental organizations, international experts on indicators, government ministers, parliamentarians, the national research team, and members of civil society and the media.

As part of the ICNRD-5 follow-up activities, Mongolia adopted a $9^{\text {th }}$ Millennium Development Goal (MDG-9) on human rights, anti-corruption and democracy. Like the other MDGs, the specifically Mongolian MDG has three targets: (1) to uphold the rights found in the Universal Declaration of Human Rights, (2) to uphold and inculcate democratic principles and values, and (3) to show zero-tolerance of corruption. At the June 2006 follow-up conference, 


\section{G. C huluunbaatar and Todd L andman}

the Government of Mongolia committed itself to using this MDG to establish a national mechanism for a process of continuous monitoring of democracy as a means for further democratic consolidation and reform.

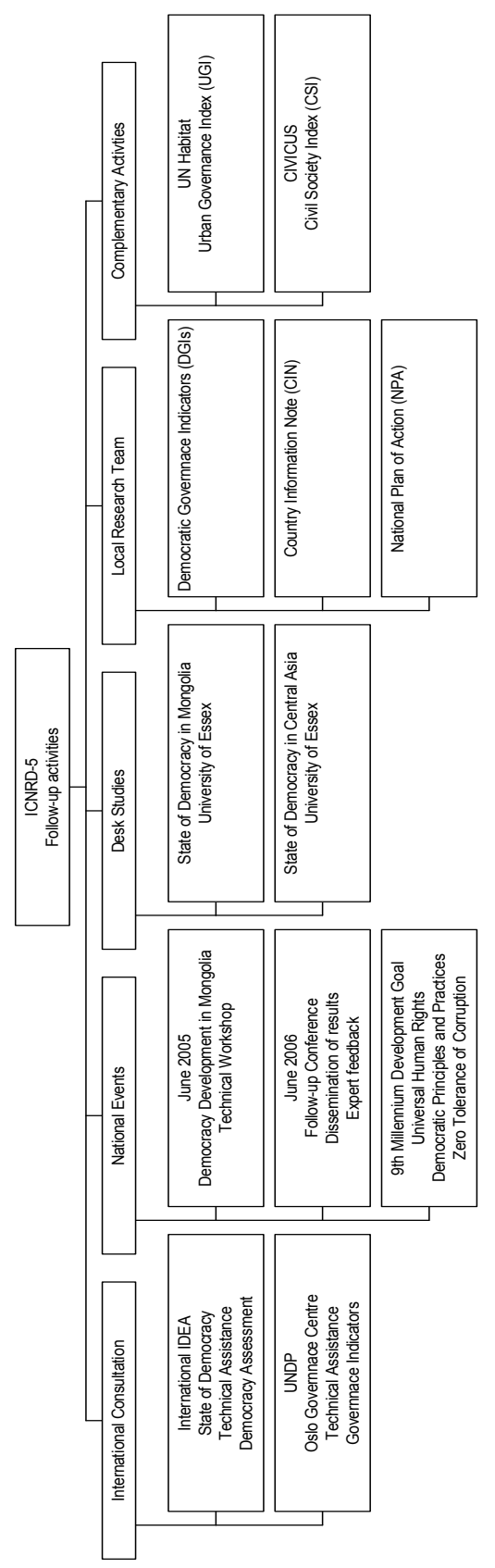




\section{Methods}

The follow up activities, and in particular the work on assessing democracy and developing democratic governance indicators employed a series of mixed methods drawn from mainstream social, legal, and political sciences. This effort to assess the quality, depth, and breadth of the democratic experience drew on multiple sources of information and data in an attempt to 'triangulate' the democratic assessment and provide an inclusive process for democratic discussion and reform.

The main data collection and analysis programme of research used the International IDEA 'state of democracy' framework founded on the following two fundamental democratic principles:

1. popular control over public decision making and decision makers,

2. equality of respect and voice between citizens in the exercise of that control

These two principles are then expressed through the following seven mediating values:

1. participation

2. authorisation

3. representation

4. accountability

5. transparency

6. responsiveness

7. solidarity

The achievement of these mediating values in turn relies on a series of requirements and institutional means with which to realise them. The combination of principles and values yields four main pillars of assessment each with additional sub-categories of analysis (See Table 1), which were used to orient the entire assessment project.

Table 1. Pillars and Sub-Categories of Democracy Assessment

\begin{tabular}{|l|l|}
\hline \multicolumn{1}{|c|}{ Main Pillars } & \multicolumn{1}{c|}{ Sub-Categories } \\
\hline Citizenship, Law, and Rights & $\begin{array}{l}\text { Nationhood and citizenship } \\
\text { The rule of law and access to justice } \\
\text { Civil and political rights } \\
\text { Economic and social rights }\end{array}$ \\
\hline \multirow{3}{*}{$\begin{array}{l}\text { Representative and Accountable } \\
\text { Government }\end{array}$} & $\begin{array}{l}\text { Free and fair elections } \\
\text { Democratic role of political parties } \\
\text { Government effectiveness and accountability } \\
\text { Civilian control of the military and police } \\
\text { Minimizing corruption }\end{array}$ \\
\hline
\end{tabular}




\begin{tabular}{|l|l|}
\hline $\begin{array}{l}\text { Civil Society and Popular } \\
\text { Participation }\end{array}$ & $\begin{array}{l}\text { Media in a democratic society } \\
\text { Political participation } \\
\text { Government responsiveness } \\
\text { Decentralisation }\end{array}$ \\
\hline Democracy Beyond the State & International dimensions of democracy \\
\hline
\end{tabular}

The national research team used qualitative and quantitative methods to gather and analyse the data and information within the IDEA framework. Qualitatively, the research tem used dialogues $(\mathrm{N}=12)$, focus groups $(\mathrm{N}=36)$, and narratives about democracy in Mongolia. The research identified concerns about the democratic experience and how that differs across different groups comprising Mongolian society. Quantitatively, the research team collected administrative statistics, elite surveys $(\mathrm{N}=118)$, mass surveys $(\mathrm{N}=1000)$, and expert judgements $(\mathrm{N}=5)$. In addition to the activities carried out by the national research team, the project carried out an assessment of urban governance in Ulaanbaatar using UN Habitat's methodology for producing an urban governance index (UGI) and an assessment of the quality of civil society using the CIVICUS methodology for producing a civil society index (CSI).

The main objective of developing an Urban Governance Index for Ulaanbaatar was to identify priority areas and subsequent actions that can be taken to strengthen urban governance. The workshop for the assessment was held in January 2006 involving participants from the city government, national government, international organisations, domestic and international civil society, media, consumer organisations, and women's groups. The workshop assessed the quality of urban governance in Ulaanbaataracross the four areas of:
(1) effectiveness
(2) equity
(3) participation
(4) accountability.

The work on the CSI adopted a broad definition of civil society including NGOs, trade unions, chambers of commerce, apartment owners' unions, political parties, community resistance groups and mass movements, non-profit media, religious organizations, savings and credit cooperatives, informal self-help groups and philanthropic activities of businesses. The main focus of the research was on NGOs due to the greater availability of information in this field, readiness and ability of NGO activists to participate in the CSI process, as well as the growing role NGOs play in Mongolia's civil society. The research assessed the quality of Mongolian civil society across the four dimensions of:
(1) structure
(2) values
(3) environment
(4) impact 


\section{Main Outputs}

There were seven main outputs from the project, including a desk study on the state of democracy in Mongolia, a comparative desk study on the state of democracy in Central Asia and Mongolia, the Democratic Governance Indicators (DGIs), the Country Information Note (CIN), the National Plan of Action (NPA), the Urban Governance Index (UGI), and the Civil Society Index (CSI).

\section{Desk Studies: Mongolia and Central Asia}

The desk study on the state of democracy in Mongolia used the International IDEA framework for democracy assessment and complemented it with extant quantitative indicators on democratic governance in an effort to establish the trends and patterns in the main features of Mongolian democracy; provide a baseline of quantitative and qualitative democratic indicators; and identify significant gaps in the public record about the quality of Mongolian democracy that need to be addressed by the national research team in developing democratic governance indicators. The study represents a diagnostic tool for domestic institutions, research teams, and local stakeholders from the public and private sector in Mongolia for addressing problems of democratic quality and seeking ways in which to pursue significant democratic reforms.

This comparative study on the state of democracy in Mongolia and the five Central Asian republics also used the International IDEA framework and complemented it with quantitative indicators on democratic governance in an effort to establish the nature, depth, and extent of democracy in the region; provide a baseline of quantitative and qualitative democratic indicators; and identify significant gaps in the public record about the quality of democracy that need to be addressed through activities pursued under the auspices of ICNRD movement. Country delegations from the Central Asian region took part in the June 2006 Follow-up Conference.

\section{Democratic Governance Indicators}

The national research team comprising primarily G. Chuluunbaatar, D. Ganbat, Ch. Gan-Ulzii, Ts. Tsentsenbileg, P. Dorjsuren, N. Bayer, and D. Ganhuyag, $\mathrm{Kh}$. Temuujin developed a set of 'core' and 'satellite' democratic governance indicators. Core indicators measure common values of democratic governance and satellite indicators measure national characteristics of democratic governance. Core indicators are thus comparable and applicable to all democracies, while satellite indicators are contextually specific and grounded.

The development, collection, and analysis of these indicators were organized within the International IDEA framework for democracy assessment, and assistance was provided through a technical workshop in June 2005, as well as 


\section{G . C huluunbaatar and Todd $L$ andman}

throughout the project. In addition to the ninety-four 'search questions' in the framework, the national team developed a series of additional questions that probed aspects of democracy and development that are particular to Mongolian society.

The work on the development of democratic governance indicators used the four pillars from the IDEA framework to identify indicative questions, which were then analysed using focus groups, surveys, and dialogues. Ultimately, there were 117 core indicators and 14 satellite indicators. The work on democratic governance indicators resulted in the following main findings:

(1) Mongolia is a new democracy, which is undergoing a dual transition from an authoritarian political past and a command economy.

(2) Despite its Parliamentary constitutional arrangements, Mongolia is in effect a Semi-Presidential system.

(3) The development of democratic governance in Mongolia is strongly affected by its relative level of underdevelopment, sparse and unevenly distributed population, and small and highly dependent economy.

(4) Mongolia has experienced increasing population migration from rural areas to Ulaanbaatar.

(5) Identification with a strong state and attachment to paternalism is still very strong within the populace.

(6) There is greater identification with nomadic lifestyle, traditional culture and Marxist ideology than with democracy and democratic values.

(7) The rapid dual transition has led to an economically segregated society, increasing, unemployment, poverty, and corruption.

(8) There is reverse gender proportionality in education, employment, and appointment to public positions, although top positions in the public and private sector tend to be held by men.

(9) Personal networks and associations provide a stronger set of social relations than legal-rational and individualistic relations.

Beyond these more general conclusions, the research revealed that the process of making information open and accessible to the public is still incomplete, there are no monitoring mechanisms for the accuracy of information, that government institutions often 'own' information and use for political advantage, and that those channels of information that do exist tend to be burdened by bureaucracy, multi-leveled government, internal rules, and regulations.

One output within the general category of democratic governance indicators is the mass survey conducted on a representative sample of over 1000 respondents. The survey questions were derived from the International IDEA framework and the analysis of the results demonstrates popular attitudes toward the democratic transition, the development of democracy in the country, the main problems that Mongolian democracy need to confront. For example, general support for democracy is higher for rural respondents than for urban respondents, while support for the democratic process itself is higher for urban respondents. Taking social strata into account shows that support for democracy and the democratic process is higher among those in the higher income strata. 
Overall, the team collected 117 core indicators and 14 satellite indicators across the various categories of the state of democracy framework. It is envisaged that through the mechanisms of the $9^{\text {th }}$ Millennium Development Goal such indicators will be collected on a regular basis in an effort to monitor the quality of Mongolian democracy, identify areas most in need of attention, and to further the process of democratic consolidation.

\section{Country Information Note}

The Country Information Note is a shorter document detailing the links between the development of Democratic Governance Indicators and the National Plan of Action. It also contains the results of an expert judgment exercise, which used the IDEA framework as a basis for judging the quality of Mongolian democracy on a scale ranging from 1 (low rating) to 5 (high rating). The experts gave a rating to a series of core and satellite questions, which were then aggregated across the four main pillars of the framework: (1) Citizenship, Law, and Rights, (2) Responsible and Accountable Government, (3) Civil Society and Popular Participation, and (4) Democracy beyond the State. Figure 3 shows that the experts rated Mongolia overall as a 3.02, which the Country Information Note summarizes as signifying a proportional mix of democratic and non-democratic characteristics, where it is clear that democracy beyond the state has received the highest rating, followed by civil society and popular participation; citizenship, law and rights; and responsible and accountable government.

\section{Urban Governance Index (UGI) and Civil Society Index (CSI)}

As complementary activities, the project team organized two exercises, which produced an Urban Governance Index and a Civil Society Index. Both these indices are based on a large collection of information and data through a broadly inclusive and consultative process. This information and data are then aggregated into quantitative scores across four categories in each index, which are represented on 'diamonds'. In this way, both indices represent 'performance profiles' where the UGI is for Ulaanbaatar and the CSI is for the whole of Mongolian civil society. The UGI revealed that Ulaanbaatar scores highest for effectiveness, followed by participation, accountability, and equity. The CSI showed the highest score for values, while equally low scores for structure, environment, and impact. Interestingly, despite the large number of registered civil society organizations, the sector as a whole remains underdeveloped and relatively weak.

\section{National Plan of Action}

The National Plan of Action aims to consolidate democracy as a pilot exercise in designing, developing, discussing, and advocating a comprehensive framework to strengthen political democracy with the participation of government, academia, 
and civil society as major stakeholders. The joint participation of the stakeholders is unique and will hopefully establish a new standard not only within the ICNRD but also in the global democratic process.

The National Plan of Action draws on the results from the entire set of followup activities to make recommendations for the continued monitoring of democracy in Mongolia and a set of steps that need to be taken to consolidate further the many democratic achievements that have been made since the transition in 1990. The plan notes that despite citizen support for democracy as the preferred form of government, there continues to be widespread dissatisfaction with the process and implementation of democracy in Mongolia. Such a gap between general levels of support for democracy as form of rule and the de facto democratic experience is not uncommon among old and new democracies, and Mongolia needs to overcome a series of challenges that are typical of new democracies, including access to information, control of corruption, limitations of state power, development of civil society, independence of the judiciary, and strengthening the rule of law more generally.

With these challenges in mind, the National Plan of Action identifies the following six main aims and objectives:

(1) Improving and broadening public participation and oversight in legislative and administrative decision making processes.

(2) Improving the organization and legislative framework for elections to uphold the right to elect and be elected.

(3) Strengthening national capacity to promote and protect human rights and fundamental freedoms.

(4) Ensuring freedom of information and enhancing protections for media independence.

(5) Establishing a national system and programme for civil democracy education.

(6) Creating the conditions for equal opportunity for participation and fair competition in the political and socio-economic arenas.

These main aims and objectives are to be realized by 2016, while the National Plan of Action also identifies a series of short-term and long-term outcomes (see Table 2).

Table 2. Short-term and long-term democratic outcomes

\begin{tabular}{|l|l|}
\hline \multicolumn{1}{|c|}{ Short-term outcomes } & \multicolumn{1}{c|}{ Long-term outcomes } \\
\hline $\begin{array}{l}\text { Creation of a favourable environment } \\
\text { for comprehensive public participation }\end{array}$ & Strengthen democratic consolidation \\
\hline $\begin{array}{l}\text { Advancement in civil political culture } \\
\text { of all citizens }\end{array}$ & $\begin{array}{l}\text { Guarantee openness, transparency, and } \\
\text { accountability for all state policies and } \\
\text { activities }\end{array}$ \\
\hline $\begin{array}{l}\text { Strengthening the relationship } \\
\text { between the state and citizens }\end{array}$ & $\begin{array}{l}\text { Instillation of democratic values and } \\
\text { democratic beliefs }\end{array}$ \\
\hline
\end{tabular}


Role of Democracy Assessment Tools in Democracy Consolidation:

Lessons Learned From Mongolia

\begin{tabular}{|l|l|}
\hline Creation of a fair electoral system & Constrain state power and reduce corruption \\
\hline Professionalization of state institutions & $\begin{array}{l}\text { Strengthen and democratize political party } \\
\text { organizations }\end{array}$ \\
\hline
\end{tabular}

\section{Outcomes and Lessons}

It is clear that the set of follow up activities was successful in carrying out a national assessment of the quality of Mongolian democracy. The activities were state-led but broadly inclusive of Parliament, civil society, academia, and the media. The whole process was also receptive to international assistance in the form of expert advice on technical issues involving assessment criteria and indicators, as well as general advice on support for democratic consolidation. It is also clear from the activities and outputs, that the whole process established a firm link between the assessment and consolidation of democracy. Developing and collecting democratic governance indicators, carrying out mass and elite surveys, engaging in focus groups and dialogues, and organising national events and public forums have all contributed to identifying concrete challenges and possible solutions to these challenges in an effort for bring about further consolidation of democracy in Mongolia. The achievements of the follow-up activities thus sit squarely in the main aims and objectives of the ICNRD movement.

The project has built capacity within government, the academy and within civil society. The three pillars of the ICNRD (government, parliament, and civil society) worked well, and there was general cooperation among the three sectors on this project. There was a general consensus that while international assistance was welcomed, this was primarily a domestic project with domestic intellectual and social capital.

\section{(1) Institutionalising democratic assessment}

One of the main outcomes is the institutionalisation of the process for producing annual (or at least periodic) monitoring documents on the state of democracy on Mongolia, which is then linked to the short-term and long-term outcomes in the National Plan of Action. Mongolia in this regard stands alongside The UK Democratic Audit and Australian Democratic Audit, which have carried out ongoing democratic assessments. It is a leader in this field, since it has undergone a stateled assessment process that is ultimately more powerfully linked to a democratic reform agenda.

\section{(2) MDG-9}

The passage of MDG-9 links Mongolia's desire to consolidate democracy to a larger strategy of poverty reduction and the realisation of the other MDGs. Even though MDG-9 is a nationally owned idea and policy initiative, it can be linked to the larger international development agenda, especially in a country whose experience with democracy is intimately connected to its transition from a command economy to a thus far weakly regulated market economy. 


\section{Conclusions}

Overall, it is clear from this paper that the main aims and objectives of the follow-up activities to ICNRD-5 were successfully achieved through a blend of state-led initiatives that were broadly inclusive of parliamentarians, academia, civil society, and the media. The various activities demonstrated a direct link between the assessment of democracy (DGIs, CIN, UGI, CSI) and the consolidation of democracy (NPA). Carrying out the activities helped build national capacity for democratic assessment and democratic reform across the different sectors and showed a remarkable degree of cooperation and understanding between state and non-state actors. Despite the many unique features that characterise Mongolia, the follow-up activities reflect a common set of challenges faced by many new democracies, as well as many mature democracies, suggesting Mongolia joins other democracies in the world in struggling to develop longlasting democratic institutions and to inculcate deeply felt democratic values. In addition to the general sense of cooperation at the domestic level, the follow-up activities were carried out in a spirit of international cooperation, and in many ways set a milestone in the idea of supporting democracy worldwide. Nationalled democracy assessment processes linked to a sensible and concrete reform agenda provide a grounded method for consolidating democracy that involves key stakeholders and provides a sense of national ownership that is crucial for long-term democratic sustainability. Finally, the institutionalisation of the followup activities through the passage of the $9^{\text {th }}$ Millennium Development Goal on human rights, anti-corruption, and democracy adds further weight to government commitment to strengthening democracy and ties the Mongolian process to the larger global agenda represented by the other MDGs.

The follow-up activities provide valuable lessons for ICNRD-6:

1. Democracy assessment provides a useful tool for the process of democratic consolidation.

2. The process of democracy assessment should be inclusive, involving members of governmental institutions, parliament, civil society and the media.

3. The process of democracy assessment should be nationally-based while drawing on international experiences and expertise from around the world.

4. Democracy assessment can pay careful attention to the unique features of a country, while maintaining comparative element.

5. Democracy assessment should adopt a mixed methodology that is multidisciplinary to yield robust substantive knowledge about the current state of democracy, as well as provide concrete aims and objectives for future democratic development.

6. Democracy assessment and the process of democratic development should be institutionalised through the establishment of national institutions and mechanisms. 